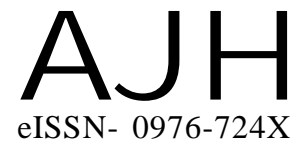

Received : 09.01.2016

Revised : 12.04.2016

Accepted : 24.04.2016
Members of the Research Forum

Associated Authors:

${ }^{1}$ College of Horticulture, University

of Horticultural Sciences,

BAGALKOT (KARNATAKA) INDIA
Author for correspondence : V.P.SINGH

College of Horticulture, University

of Horticultural Sciences,

BAGALKOT (KARNATAKA) INDIA

Email : vpsingh.neev@gmail.com
THEASIAN JOURNALOF HORTICULTURE

Volume 11 | Issue 1 | June, 2016 |52-57

Visit us -www.researchjournal.co.in

RESEARCH PAPER

DOI : 10.15740/HAS/TAJH/11.1/52-57

\section{Influence of different media on shoot regulation, shoot multiplication and callus induction in long pepper (Piper longum L.)}

\author{
S. MALTHI ${ }^{1}$, V.P. SINGH, S.S. SARASWATI ${ }^{1}$, H.T. SAKHUBAI ${ }^{1}$ AND P.M. \\ PREETI $^{1}$
}

ABSTRACT : An experiment on tissue culture studies in long pepper (Piper longum L.) was carried out in the year 1999-2001, to develop suitable protocol for plant multiplication technique at Green Earth Biotechnologies Ltd., Jigani Industrial Area, Bengaluru in collaboration with UAS, GKVK, Bengaluru. The concentration of 0.1 per cent mercuric chloride $\left(\mathrm{HgCl}_{2}\right)$ for 60 seconds to achieve disinfection of leaf segment explants was found effective, giving maximum survival $(10.02 \%)$ and minimum contamination $(0.70 \%)$. MS media containing BAP $(1.5 \mathrm{mg} / \mathrm{lit}$.) $+2,4-\mathrm{D}(1.0 \mathrm{mg} / \mathrm{lit}$.) from leaf explants gave higher $(9.72 \%)$ response for calli induction, $1.54 \mathrm{mg}$ amount of callus with green colour and very good score of callus. BAP $3.0 \mathrm{mg} / \mathrm{lit}$. was ideal for the better proliferation and regeneration of shoot $(40 \%)$. The Highest number of multiple shoots (2.00), Length of shoot $(1.04 \mathrm{~cm})$ and number of leaves per shoot (3.00), was produced using BAP $(1.0 \mathrm{mg} / \mathrm{lit})+.\mathrm{NAA}(0.1 \mathrm{mg} / \mathrm{lit}$. $)$. Best results for shoot were observed with the MS media combination containing BAP at $1.5 \mathrm{mg} / \mathrm{lit}$., Kinetin at $1.0 \mathrm{mg} / \mathrm{lit}$. and IAA at $0.5 \mathrm{mg} /$ lit., gave the maximum number of buds per calli (36.00) and number of shoots (5.20) and length of shoots $(1.62 \mathrm{~cm})$. The in vitro rooting was achieved with the application of NAA at $1.0 \mathrm{mg} / 170$ per cent rooting, number of primary roots (2.40) length of primary root (2.00) and number of secondary roots $(2.00)$.

KEY WORDS : Long pepper, In vitro, Micropropagation, Tissue culture, MS media

HOW TO CITE THIS ARTICLE : Malthi, S., Singh, V.P., Saraswati, S.S., Sakhubai, H.T. and Preeti, P.M. (2016). Influence of different media on shoot regulation, shoot multiplication and callus induction in Long Pepper (Piper longum L.). Asian J. Hort., 11(1) : 52-57, DOI : 10.15740/HAS/TAJH/11.1/52-57. 